\title{
Role Of Total Quality Management In Service Innovations: An Empirical Study Of Pakistan's Financial Services Firms
}

Arif Mohammad Arshad, Xi'an Jiaotong University, China

Qin Su, Xi'an Jiaotong University, China

\begin{abstract}
This empirical study examines the relationship between total quality management (TQM) and service innovation as well as the relationship between service innovation and service quality in the Pakistan's financial services industry. Most of the past research linked innovation performance with subjective performance of the firm. But, this study empirically evaluates the effect of innovation performance on firm's judgmental performance (Service quality).There were 190 respondents from financial service firms in Pakistan. Multiple regression analysis was used to observe the connection between TQM, service innovation practices and service quality. A model is proposed based on theoretical considerations, connecting TQM constructs to the service innovation and to the service quality construct. The theoretical construct explains the connection among TQM practices, service innovation practices and service quality. The tri-dimensional relationship bridges the gap between TQM, service innovation and service quality and shows the importance of TQM in explaining the relationship between service innovation and service quality. This research also integrates the connection among TQM implementation, Service innovation practices and service quality. Data analysis shows that TQM implementation has a positive and significant impact on service innovation as well service quality. It has contributed in confirming that TQM practices deployed in a financial service firm in Pakistan has positive impact on service innovation and service quality.
\end{abstract}

Keywords: TQM; Service Quality; Service Innovation; Service Industry; Process Innovation; Product Innovation

\section{INTODUCTION}

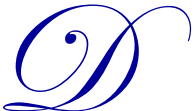

uring the last two decades the importance of service sector is increasing in international markets. The significance of service sector is obvious almost by any economic measure chosen by all considerations, services reign over the majority of developed economies .The share of service sector is somewhat even more than half of countries' GDP and the projected economic and job growth in the 21 st century is predicted to be reigned over by services. Due to fierce competition in international markets, firm's growth and development largely depends on innovation. Organizations by providing extraordinary innovative services can achieve competitive advantage in the service industry.

TQM is internationally recognized superior quality approach that leads to development of high quality products and services and improves organizational performance (Lam et al., 2012).TQM is a management model that aims to achieve customer satisfaction through continuous improvement by combining all the processes within an organization(Prajogo \& Sohal, 2006). TQM emphasis on producing high quality outputs, at the same time creating a healthy work environment by encouraging and supporting workers. The implementation of TQM in service industry results in delivering higher service quality and attainment of higher customer satisfaction. The innovation process can be enhanced by the implementation of TQM elements (Bon and Mustafa, 2013). The key objective of TQM is to enhance customer satisfaction by providing high quality products and services that can be achieved by implementing systematic methods for continuous improvements. The implementation of TQM 
principles not only results in superior service quality but also improve organizational performance (Cook and Verma, 2002).

Business innovation is a key factor for organizations to adopt total quality managing systems in rapidly changing world for their survival and growth. In a business environment, organizations through innovation meet customer demands, stay profitable, introduce new products and services, develop new technological capabilities and search for new business processes. In short, innovative firms are more competitive. Innovation also plays important role in achieving higher standard of living, development of economy, acquiring and sustaining higher performance of firms (Ar and Baki, 2011). The TQM implementation approaches for products and services are somewhat different from each other. The services are intangible in nature and dependent on customer's evaluation. Therefore, services firms are mostly customer driven and focus more on customer satisfaction (Juneja et al., 2011). Manufacturing firms are more process oriented and focused more on product quality and lay more importance to factors like social responsibility, ISO certification and environmental issues (Mohapatra et al., 2010)

According to Prajogo and Sohal (2001) today's market environment is more focused on innovation rather than on quality as innovation has become one of the sources of the competitive advantage. Since TQM principles were developed to pursue quality, therefore it has become important for organizations to validate to role of TQM in service innovation. They identified two schools of thoughts with contrary views about the impact of TQM dimensions on innovation. According to one school of thought TQM practices have positive relationship with innovation performance and while others narrate TQM principles obstruct organization's innovation performance. The studies on innovation in service sector are few and far between. The research contributions in the areas of service innovation have evolved slowly especially about new product development and innovation (Oke, 2007).

It is evident there is deficiency in literatures in studying the link between TQM practices and service innovation. Also, little research is carried out about TQM impact in service industry and most of past researches were in the areas of both service and manufacturing industry. There is shortage of research about the influence of TQM principles on service innovation (Oke, 2007), particularly in Service sector of Pakistan. The impact of service innovation on service based element like service quality is of particular importance for formulating and implementing innovation strategy (Lei, 2011). Service industry of Pakistan contributes 54 percent of GDP and its contribution is higher than agricultural and industrial sector. Service sector provides more than one-third of total employment and it has strong bond with other sectors of the economy. Therefore, it will be exciting to examine the relationship among TQM, service innovation and service quality in Pakistan's financial service sector.

This paper investigates the tri-dimensional relationship among TQM practices, service innovation and service quality in the financial service industry of the developing country. By using multiple regression analysis, this study examines the direct and indirect impact of each construct on service quality. Also, study examines the strength of relationship between TQM, service quality and service innovation as well as the relationship between service innovation and service quality. This study improves the level of knowledge about TQM practices on service innovation and the influence of service innovation on service quality in the service sector. Most of past studies linked service innovation with subjective performance of the firm. This study empirically evaluates the influence of service innovation on organization's judgmental performance (Service quality).

\section{LITERATURE REVIEW}

\subsection{TQM}

In Today's competitive world TQM is playing vital role in the achievement of excellence in product and service quality. The implementations of TQM in organizations make them more effective in the global markets (Zakuan et al., 2008; Hoang et al., 2006; Bon and Mustafa, 2013). The successful implementation of TQM helps organizations in developing methods and services that cannot be easily imitated by the competitors (Dale, 2003). TQM practices emphasis on development of methods and procedures that are cost effective with the things being finished right from the first time with minimum waste from operations (Lam, 2012). The ultimate goal of TQM is to become more competitive, revenue growth, innovation and improving firm performance. 


\subsection{TQM Practices}

After the broad review of TQM literature, we have selected the following seven TQM dimensions Top management commitment, Customer focus, Continuous improvement, Information system quality, Knowledge sharing, ICT usage, service culture.

\subsection{Top Management Support}

The successful implementation of TQM relies on leadership commitment and personal involvement. Top management plays critical and decisive role in bringing strategic changes in important areas like innovation, product development and quality management (Hoffman and Hagerty, 1994). Therefore, Top management's focus should be on meeting customer's expectations. Their commitment is crucial for the effective TQM efforts because they create and implements quality values that are vital for achieving organizational goals( Zairi , 2002). Top management should have transformational leadership skills and the ability to develop an environment in which employees can work together independently and interdependently.

\subsection{Customer Focus}

Customer focus is one of the important dimensions of TQM. The aim of TQM practices is to satisfy internal and external customers by continuously improving the work processes through customer's opinions (Lee and Chang, 2006). Manufacturing firms produce tangible goods whereas service providers provide services that are intangible in nature. Therefore, service firms need to think in a very different way as the expectations of their customers are very dynamic and complex in nature. Therefore, in order to satisfy customer, service firms should put their efforts on customer-defined areas (Sureshchandar, 2001). The successful organizations always put their customers first in every decision they made. Therefore, organizations should build close relationships with their customers in order to get feedback about their products and services (Flynn et al., 1994). Organizations should regularly assess the customer expectations and adjust their operations according to the changing demands of their customers (Takeuchi \& Quelch, 1983). In order to deliver better service quality and customer satisfaction, organizations should be made customer oriented and treat their complaints with top priority (Zhang et al., 2000).

\subsection{Continuous Improvement}

Continuous improvement is an important dimension of TQM as it leads to cost reduction thereby reducing the number of defects. Continuous improvement reduces the failure rate and increases the success rate. The quality of the products and services can be improved by continuous improvement. Organizations can satisfy their customers by continuously improving the quality of their products and services. As the customer expectation's change with time, so their expectations about the product \& services offered also change with time. Therefore, organizations should consider new ways of improving their products and services. Moreover, continuous improvement should be directed towards inputs and processes that are under the control of the manager. In order to improve quality and achieve long-term profits and customer loyalty, managers should continuously focus on improving organizational processes and inputs (Scholtes et al., 1988).

\subsection{Information System's Quality}

In this modern era, due to technological advancements, organizations are growing at rapid pace. Therefore, organizations heavily depend on quality information systems (IS) for their success. An organization with the help of IS collect and organizes data to create the desired information at all levels. IS are used as a key information tool to solve business problems and they are based on up-to-date different types of information's that are helpful for managers in making managerial decisions. Information technology and quality information systems play important role in the success of organizations and have been identified as a significant factor that impacts service quality (Bharati and Berg, 2003). The use of IS can help organizations in improving their quality through reductions of costs, better awareness of quality, high speed processing of quality data and availability of information about the quality management (Mjema et al, 2005). The implementation of IS quality management practices helps organizations in improving system quality, development costs and project schedule (Ravichandran and Rai, 2000). 
Effective IS are very efficient in providing customers information in timely manner. Tama et al. (1998) presented evidence from the empirical study that IS and information technologies are critical elements of TQM. Siddique et al. (2007) through their case study research showed that TQM and IS are helpful in improving the quality of products and services to their customers.

\subsection{ICT (Information And Communication Technology) Adoption}

ICT adoption has brought about big changes in communication, sales and information retrieval methods (Lapierre and Denier, 2005). It has been observed by numerous recent studies that ICT adoption has positive impact on firms' productivity in terms of profitability, market share and market value. ICT adoption also has a positive effect on intermediate performance measures like service quality, cost savings and customer satisfaction.( Melville et al., 2004; Kohli and Devaraj, 2003; Dedrick et al., 2003). According to some empirical studies organizations can materialize greatest benefits from ICT when their ICT investments are aligned with organizational changes like new organizational structures and new business strategies (Brynjolfsson et al., 2000). Information and communication technology also plays significant role in service innovation (Miles, 2005). There is considerable literature available that argues ICT usage support TQM because it makes it more efficient and results in increasing the business value.( Dewhurst et al., 2003, Martinez-Lorente et al., 2004; Loukis \& Pazalos, 2009).

\subsection{Knowledge Sharing}

Quality knowledge is backbone of all the organizations. In today's competitive business environment, organization's survival mainly depends on the management of quality knowledge. The TQM approach views quality knowledge as a source of competitive advantage. A knowledge sharing culture is very important for the successful implementation of TQM practices because it maintains their competitiveness, generates useful information for decision making, increase long term competitive advantage and encourages creativity and innovation (Wang, 2009; Apostolou et al., 2008; Zhao \& Bryar, 2001). The organizations whose employees are equipped with right kind of knowledge will have the competitive advantage over its competitors (Han \& Anantatmula, 2007) .

\subsection{Service Culture}

Service culture is of great importance in TQM literature. The purpose of developing service culture is "service to customers". Organizations which believe in service culture are more likely to provide reliable, responsive and empathetic service to the customers. The service culture improves service quality from customer's perspective (Sureshchandar et al., 2001; Hoang et al., 2006). The features of service business are intangibility, inseparability, heterogeneity, perish ability, etc. It is difficult for management of service firms to directly supervise their employees when they are dealing with their customer because it will affect seamlessness of service. Therefore, service firms should develop a service climate that have core values, mores and beliefs that guide employees behavior in different departments of the organization like marketing, operations and HRM. An organization having good service culture is more likely to provide more reliable, responsive, empathetic service to the customers. A strong internal service culture is likely to lead to improved service delivery which in turn leads to better perceived service quality from customer's point of view (Sureshchandar et al., 2001).

\subsection{Service Innovation}

Innovation is defined as "the act of introducing something new" (American Heritage Dictionary of the English Language, 2000). The aim of innovation is to identify new opportunities in order to make new products, services or work practices (Axtell et al., 2000). The service innovation differs from product innovation in many ways. First, service delivery staff is part of innovation in case of labor-intensive interactive services. Second, the services that involve the physical presence of customer need "local" decentralized production capacity .Third, service innovations do not carry brand names like an iPod or Samsung (Berry et al., 2006).

The interaction with customers is an essential part of their service offerings. Therefore, service suppliers must build up suitable form of service product and proper way of interaction with customers because developing a new service is far more difficult than the development of new tangible product (Johne and Storey, 1997). According 
to numerous researchers, service innovation enables firms achieving competitive advantage (Kaplan, 2000). The benefits that accrue from starting new services include increase in the profitability, enhancing the customer satisfaction and loyalty of existing customers and the opportunity for opening new markets (Sampson, 2002).

Due to technological advancements service firms are growing very fast and the competition amongst them is getting fierce day by day. Therefore, these firms are working very hard to provide high-quality service to their customers better than their competitors. These service organizations are moving their attention towards the implementation of TQM principles in service organization to offer better service quality to their customers (Rönnbäck and Witell, 2008).

\subsection{Service Quality}

Service quality play vital role in achieving sustainable competitive advantage. Satisfied customers increase organization's profitability by repeat purchase, brand loyalty and positive word of mouth. Service quality is the comparison of customer expectations with performance. Delivering service quality means fulfilling customer expectations on regular basis. During evaluating service quality customers compare the expected services with the services they receive. It is perceived judgment that is measured by comparing the customer expectations from the service and the level of service perceived by the customer (Parasuraman et al., 1998).

Parasuraman et al. (1988) developed a scale to measure the service quality of different services provided by the service providers. It is one of the fundamental instruments used to measure perceived service quality and has been verified by numerous past studies. The widely used SERVQUAL model is consist of five dimensions which suggest that customers focus on five dimensions in their assessment of services that are: Tangibles, reliability, responsiveness, assurance, and empathy. Service quality is the customer's overall judgment of excellence of service offering (Santos, 2003). Service quality is also influenced by capability of an organization in satisfying customer needs in accordance with their expectation level (Yoo \& Park, 2007). Gronoos(1984) has presented his own two dimensional model of service quality. He argued that service quality is a function of two variables: technical quality and functional quality. The technical quality deals with what is delivered whereas functional quality entails how it is provided. Customer loyalty is of great importance in the current literature because it's the primary force to boost firm's financial performance in the current business environment. Superior service quality is of fundamental importance in enhancing customer loyalty. It has been proved from previous research that there is positive correlation between service quality and customer satisfaction (Cronin et al., 2000). Service quality is also closely linked with customer's intention to stay close to their service provider (Anton et al., 2007).

\section{RESEARCH FRAMEWORK \& HYPOTHESIS}

\subsection{Relationship Between TQM Practices And Innovation}

Service innovation is an important feature of firm's capability to differentiate itself from its competitors and add more to firm's revenue. Innovations can enhance service differentiation; therefore it is essential for managers to implement those innovations that are desired by the customers to generate revenues for the firm (Dev et al., 2005). The recent literature found direct and positive relationship between innovation and performance in different service sectors (Lin, 2011). Firms which clearly define their innovation process for services are more swift and successful in developing new services. The development of new services leads to higher revenue growth as well as increase in the share of their total revenue. Today's business environment is very competitive and therefore just providing quality services is not enough, companies should seek for new innovative service offerings that are valuable for customers(Bettencourt et al., 2013). Therefore companies should pay more attention to their innovation strategy, processes and especially their services to make innovation process more systematic (Schulteß et al., 2010). Successful innovation strategies are more useful during the recession times when there is decrease in economic activity due to decrease spending. Service innovation is a big source of competitive advantage for those companies which capitalize on knowledge gained from customers, competitors and have the potential to develop more meaningful and unique services. 
The relationship between TQM and innovation is compound one due to the diversity of TQM practices (Bon \& Mustafa, 2012 in press). The study conducted by McAdam et al (1998) in Ireland found that organizations should improve their continuous improvement programs because they provide foundation for building an innovation organization. Another view about the relationship between TQM and innovation is that innovative firms work in more systematic fashion due to couple of reasons. First, they identify the customer's needs and secondly they are swifter than their competitors in developing innovative products or services. Finally, they follow ISO 90001 quality management systems (Mielgo et al, 2009).

On the other hand, Leavengood and Anderson (2011) found that quality oriented firms are not innovative because they over emphasis on the customer needs and are proactive towards customer needs. According to the study of Singh \& Smith(2004) there is no clear empirical evidence of positive and significant effect of TQM practices on innovation, while (Prajogo and Sohal, 2001) predicted TQM practices could have bad effect on innovation due to certain practices. Also, most of the studies were carried out in developed nations. There is lack of research work concerning the relationship between TQM practices and innovation developing nations like Pakistan.

\subsection{Relationship Between TQM Practices And Service Quality}

The numerous past studies have revealed positive link between TQM and quality performance (Samat et al., 2007). The aim of TQM implementation is to guarantee that the company fulfills the candid needs and demands of customers. Therefore, implementation of TQM has positive correlation with service quality. The key purpose of TQM implementation is to improve quality performance of products and services (Juran, 1988; Samat et al., 2007). Kersten and Koch (2010) studied the influence of TQM practices in German service sector. They found that service quality mediate between quality management practices and financial performance. Sit et al. (2011) studied the effect of TQM practices on service quality in twenty Malaysian commercial banks. Their results indicated strong correlation between TQM practices and service quality. Lam et al. (2012) in their empirical study found that TQM has positive and significant relationship with service quality. Thus, we can hypothesize that

H1: TQM can positively influence firm's service quality. 


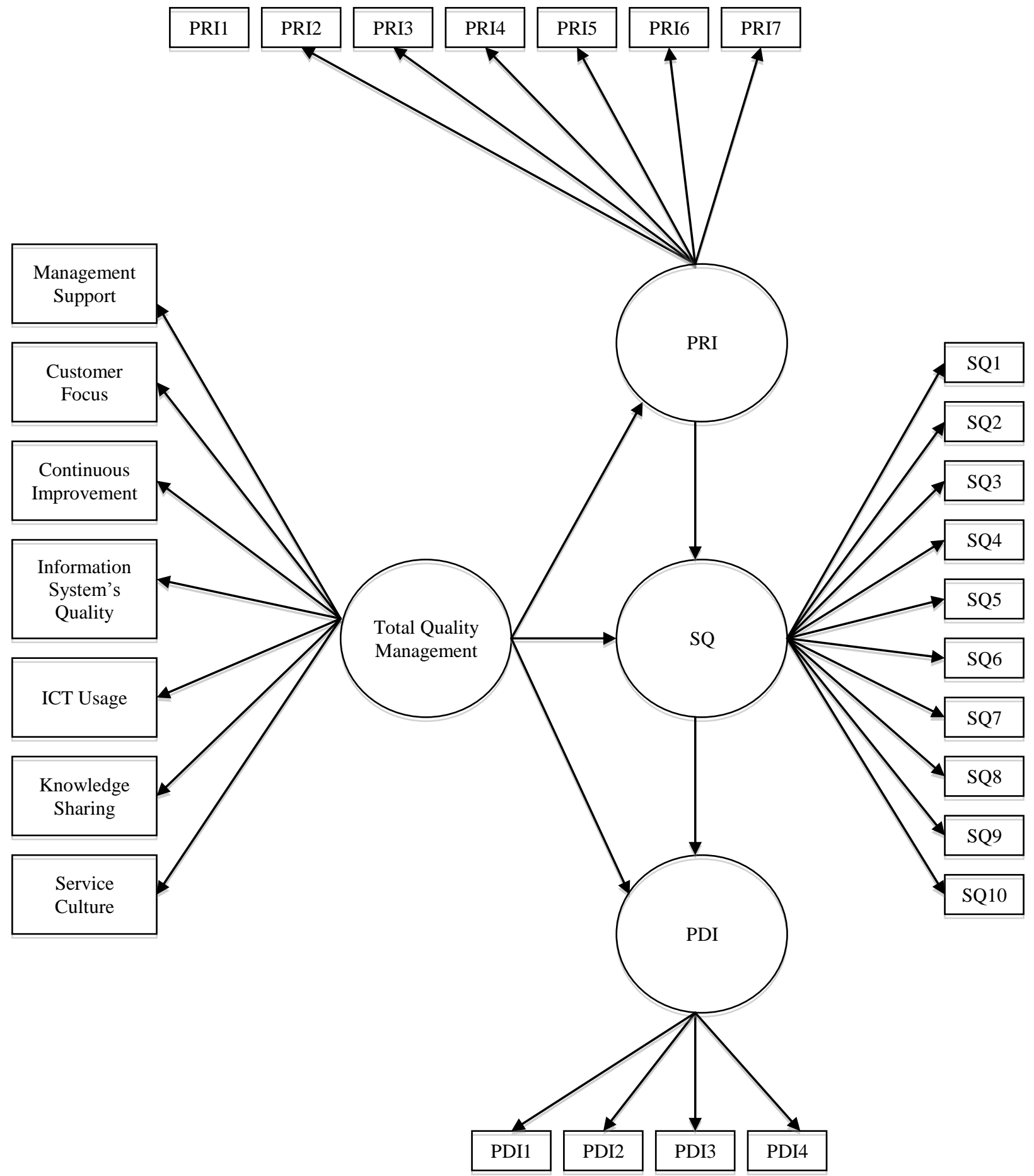

Figure 1. The Conceptual Model

\subsection{Relationships Between TQM Practices And Service Product Innovation}

The key objective of product innovation is to accomplish the demands of the customers or capture external markets. Service product innovation is further classified into two sub-categories-radical product innovation and incremental product innovation. Service product innovations are the introduction of new offerings in the core of current services is the most common kind of innovation that may lead to new business benefits. The purpose of 
service innovation is to make the services more attractive to consumers by adding new flavors in the core of existing services (Khazanchi et al., 2007)

Firms get momentum for market leadership and growth by making product improvements and adding new products to their product line (Iansiti, 1995). Product innovation opens new markets to the firm by attracting new customers. Product innovation also open firms in market share growth by adding new customers in the existing markets (Zahra \& Nielsen, 2002). The management of successful organizations show more commitment to the development of new product especially in terms of delivering sufficient funding and resources than less successful organizations ( Kuczmarski \& Associates ,1994). A study from Mercer Management Consulting (1994) reveals that management of high performance companies is highly committed in the implementation of new product development strategy. The service products are more easy to copy and hard to safeguard under commercial patents. Even so, in order to remain competitive, service firms should keep working on innovating service products (Chen \& Tsou, 2007). The TQM dimension of customer focus persuade organizations to look for new customer needs and expectations and therefore direct organizations to be innovative in terms of exploring new products on continual basis in order to fulfill market's changing demands(Juran, 1988). To do so organizations needs to be creative to exceed the needs and expectations of their customers. Similarly customer focuses emphasis organizations to constantly seek for new customer's demands and expectations. This strategy is closely related with innovation. Similarly, continuous improvement motivates change and creative thinking in their business work. Finally, TQM dimensions like employee empowerment, teamwork play important part in determining the success of organizational innovation (Prajogo \& Sohal, 2001). Organizations who adopt TQM as management strategy are more innovative organizations (Baldwin and Johnson, 1996). The service firms that implement TQM practices will perform better in distinguishing their products and offering better services. The TQM dimension leadership motivates employees to present new ideas for solving problems for developing new products or services. Prajogo et al. (2008) found positive and significant relationship between TQM practices and product innovation. Therefore, we can assume that TQM implementation has positive influence on service product innovation.

H2: There is significant relationship between TQM practices and Service product innovation.

\subsection{Relationships Between TQM Practices And Service Process Innovation}

Service process innovation is the introduction of new or significantly improved production or delivery method for producing products or services for business purposes and can be implemented on whole value chain (Chen \& Tsou, 2007; Sadikoglu \& Zehir, 2010). The aim of Process innovation is to improving the productivity of the firm by creating or improving production methods or services as well as the enhancements in the development of processes, systems and reengineering activities in order to make new products or services (Garcia and Calantone, 2002; Khazanchi et al., 2007). Process innovation facilitates firms in creating large amount of products and services on the expense of limited amount of available resources. The incremental process innovation and radical process innovation are two categories of service process innovation (Reichstein and Salter, 2006).

A research conducted on British companies found that processes improvements are critical for the success of product/service innovations (Oke, 2007). Deming (1986) recommended that firms should continuously improve their products and services to satisfy their customer because it is major indictor of firm's market share and profitability. The satisfied customers increase firm's profitability by repeating their purchase of products or services. The TQM efforts resulted in increased customer satisfaction in big firms like IBM, Xerox and 3M (Ross, 1995). A study conducted by Prajogo \& Sohal (2004) on manufacturing and non-manufacturing firms found TQM practices have positive and signification impact on product and process innovation. Martínez-Costa and Martínez-Lorente (2008) suggest that continuous improvement bring change in organizations and this change leads to innovations in the organization.

Therefore, we can assume that TQM adoption has positive result on service process innovation

H3: There is significant relationship between TQM practices and service process innovation 


\subsection{Relationships between Service quality and service innovation (process innovation \& product innovation)}

According to different studies being innovative can lead to growth in business performance in service firms. Cainelli et al. (2004) in their study investigated the effect of innovation on financial performance in service firms. He found that innovative firms perform better than non-innovative firms. The service firms can attain superior financial performance through differential positional advantage, innovative features and offering higher product quality (Day and Wensley, 1988). The service organizations can also take benefit from innovation ( Jeroen et al., 2003). According to already available literature, it has been found that service innovation not only increases the business revenue but also brings out other benefits for service firms like creating customer value and better strategic success (Vermeulen et al, 2003).

It is obvious from the past research that there is positive effect of service innovation on customer's choice. A study by (Victorino et al., 2005) investigated the effect of service innovation in the hotel industry. They found that service innovation have big impact on the guests living in economy hotels as compared to upscale hotels where as innovative services like technological improvements and customization have larger impact on leisure hotels. Lin (2011) in his study about tourism industry of China studied the effect of service innovation on firm performance in which service quality played the mediating role. He discovered the positive effect of service innovation on both service quality and firm performance. Innovation has a lot of types, but most of the past studies include only one construct in the innovation literature. To overcome this deficiency, this study consists of two innovation types, product and process. By employing resource-based view, we developed our next hypothesis described below:

H4: Service product innovation has positive and significant influence on service quality

H5: Service process innovation has positive and significant influence on service quality

\section{RESEARCH METHODOLOGY}

The unit of analysis is financial industry in Pakistan. In our study, we used survey questionnaire to examine the relationships amongst TQM practices, Service innovation and service quality in the financial industry. We obtained information about TQM practices, service innovation and service quality from different financial firms in Pakistan. The data obtained from survey questionnaire were used to study the effects of TQM practices on service innovation and service quality. We selected financial service firms to carry out this research work. The choice of financial industry is because it's more competitive, dynamic and technology based industry. Due to rapid change in the business environment of financial services sector, there is rapid increase in the use of innovation-related activities in the financial services sector (Chen et al., 2007).

We used five-point Likert scale adopted from previous studies for measuring our constructs. Our survey questionnaire was consisting of four-page self-administered questionnaire previously used in comparison of quality management practices in different countries. These people are most knowledgeable people regarding research issues of our study. We circulated total of 300 questionnaires to people that are most knowledgeable regarding research issues of our study. We obtained 190 with thorough replies which signify an overall response rate of 63 percent. The data is collected from ISO certified firms from financial services industry of Pakistan. The statistical tools such as correlation and regression were applied to interpret the data.

\subsection{Measures}

This study is consist of seven TQM dimensions that are top management support, customer focus, continuous improvement, quality information system, ICT usage, service culture and knowledge sharing. The questions related to TQM dimensions selected in this study are based on past works of Sureshchandar et al. (2002), Brah et al. (2002) and Prajogo and Sohal (2006). The scale of process innovation were embraced from Chen et al.(2007) and Davenport and Short (1990).The questions about product innovation were adopted and modified from the research work of Chen et al.(2007) and Avlonitis et al.(2001). 
The SERVQUAL construct consist of five dimensions which captures overall respondents perceived service quality in their organization. The SERVQUAL dimensions and the questions in this study are adopted from the research work of Zeithaml et al. (1990), Lassar et al. (2000) and Ooi et al. (2011). Most of the past studies about the connection between TQM practices and Service Quality focused on the managerial prospect of the service quality. Some of these studies include the research work of Lam et al. (2012), Sit et al. (2011) and Ooi et al. (2011). There are few studies that measures service quality from customer perspectives(Sureshchandar et al., 2002). This study also investigates the relationship between service innovation and service quality from the managerial perspective.

Table 1. Factor Analysis Of TQM Practices

\begin{tabular}{|c|c|c|c|c|}
\hline $\begin{array}{c}\text { Variable } \\
\end{array}$ & Loadings & KMO & Variance $(\%)$ & Cronbach's Alpha \\
\hline Top Management Support & & 0.763 & 56.632 & 0.731 \\
\hline TM1 & 0.689 & & & \\
\hline TM2 & 0.685 & & & \\
\hline TM3 & 0.743 & & & \\
\hline TM4 & 0.943 & & & \\
\hline TM5 & 0.834 & & & \\
\hline Customer Focus & & 0.815 & 71.194 & 0.865 \\
\hline CF1 & 0.764 & & & \\
\hline $\mathrm{CF} 2$ & 0.754 & & & \\
\hline $\mathrm{CF} 3$ & 0.737 & & & \\
\hline $\mathrm{CF} 4$ & 0.593 & & & \\
\hline Continuous Improvement & & 0.796 & 66.435 & 0.826 \\
\hline CI1 & 0.693 & & & \\
\hline $\mathrm{CI} 2$ & 0.667 & & & \\
\hline $\mathrm{CI} 3$ & 0.609 & & & \\
\hline CI4 & 0.689 & & & \\
\hline Information System Quality & & 0.690 & 60.958 & 0.801 \\
\hline IS1 & 0.685 & & & \\
\hline IS2 & 0.574 & & & \\
\hline IS3 & 0.565 & & & \\
\hline IS4 & 0.615 & & & \\
\hline Service Culture & & 0.800 & 73.281 & 0.869 \\
\hline $\mathrm{SC} 1$ & 0.760 & & & \\
\hline $\mathrm{SC} 2$ & 0.756 & & & \\
\hline $\mathrm{SC} 3$ & 0.713 & & & \\
\hline SC4 & 0.702 & & & \\
\hline ICT Usage & & 0.771 & 69.361 & 0.851 \\
\hline IU1 & 0.848 & & & \\
\hline IU2 & 0.885 & & & \\
\hline IU3 & 0.817 & & & \\
\hline IU4 & 0.778 & & & \\
\hline Knowledge Sharing & & 0.818 & 69.448 & 0.850 \\
\hline KS1 & 0.868 & & & \\
\hline KS2 & 0.836 & & & \\
\hline KS3 & 0.846 & & & \\
\hline KS4 & 0.781 & & & \\
\hline
\end{tabular}

\subsection{Verification Of Scales}

The construct validity was tested by using exploratory factor analysis (EFA).The purpose of applying EFA is to isolate the dimensions of each construct. The factors were extracted by applying principal component analysis individually on service quality, TQM and Service innovation criterion with varimax rotation. The factor loading of at least 0.30 is considered acceptable variable (Nunnally, 1978). In order to ensure quality of extracted factors, a factor loading of at least 0.50 was considered acceptable. During the validation process items with factor loading less than 0.5 were subsequently removed (Sit et al., 2009; Hoang et al., 2006). The results of EFA are summarized in 
Table $1 \&$ Table 2 . All the reliability values are above 0.5 which shows that all the steps in this study are valid and reliable. The internal consistency analysis was carried out to check the reliability of survey data. The Cronbach's alpha is the basic measure of the reliability which indicates relative reliability of each factor as a scale. The sufficient value of Cronbach's alpha is 0.6(Nunnally, 1967). In order to improve the reliability, items with values less than 0.6 were eliminated (Shams-ur Rahman, 2001). All of the reliability coefficient values in this study are above 0.7 which show that each factor is sufficiently reliable measure. The suitability of the sample was tested by applying KMO measure. The KMO values shown below in table 1 are generally acceptable (Shams-ur Rahman, 2001; Kim and Mueller, 1978).

Table 2. Factor Analysis Of Service Quality And Service Innovation Practices

\begin{tabular}{|c|c|c|c|c|}
\hline Variable & Loadings & KMO & Variance (\%) & Cronbach's Alpha \\
\hline Service Quality & & 0.885 & 64.614 & 0.941 \\
\hline SQ1 & 0.877 & & & \\
\hline SQ2 & 0.876 & & & \\
\hline SQ3 & 0.822 & & & \\
\hline SQ4 & 0.780 & & & \\
\hline SQ5 & 0.856 & & & \\
\hline SQ6 & 0.796 & & & \\
\hline SQ7 & 0.621 & & & \\
\hline SQ8 & 0.637 & & & \\
\hline SQ9 & 0.671 & & & \\
\hline SQ10 & 0.717 & & & \\
\hline Service Innovation & & 0.804 & 51.731 & 0.842 \\
\hline SI1 & 0.710 & & & \\
\hline SI2 & 0.628 & & & \\
\hline SI3 & 0.727 & & & \\
\hline SI4 & 0.787 & & & \\
\hline SI5 & 0.680 & & & \\
\hline SI6 & 0.696 & & & \\
\hline SI7 & 0.731 & & & \\
\hline
\end{tabular}

Moreover, Pearson correlations between each pair of independent variables is found to be significant at 0.01 level of significance (table 3 ) and does not exceed 0.90 and thus are acceptable for discriminant validity (Hair et al., 1998).

Table 3. Inter-Constructs Correlations As Discriminant Validity

\begin{tabular}{|c|c|c|c|c|c|c|c|}
\hline & TM & $\mathbf{C F}$ & CI & SC & IS & IU & KS \\
\hline TM & 1 & & & & & & \\
\hline $\mathrm{CF}$ & $0.538^{* *}$ & 1 & & & & & \\
\hline CI & $0.537^{* *}$ & $0.455^{* *}$ & 1 & & & & \\
\hline SC & $0.501^{* *}$ & $0.470^{* *}$ & $0.518^{* * *}$ & 1 & & & \\
\hline IS & $0.618^{* *}$ & $0.375^{* *}$ & $0.557^{* *}$ & $0.552^{* *}$ & 1 & & \\
\hline IU & $0.304^{* *}$ & $0.307^{* *}$ & $0.410^{* *}$ & $0.324^{* *}$ & $0.384^{* *}$ & 1 & \\
\hline $\mathrm{KS}$ & $0.404^{* *}$ & $0.405^{* *}$ & $0.499^{* *}$ & $0.474^{* *}$ & $0.476^{* *}$ & $0.471^{* *}$ & 1 \\
\hline
\end{tabular}

Notes: $\mathrm{n}=190 ; * * \mathrm{p}<0.01$; TM=Top management support; $\mathrm{CF}=$ Customer Focus; $\mathrm{CI}=$ Continuous Improvement; SC $=$ Service Culture; IS=Information System quality; IU=ICT Usage; KS=Knowledge Sharing

It is also necessary to validate that the causal relationship among the three performances measures process innovation, product innovation and service quality is genuine one or spurious. A test was applied by using partial correlation on the three performance measures while TQM was kept as a controlled variable (Prajogo et al., 2003). The results presented in the table 4 are significant at the level of 0.01 . This shows that there is genuine causal relationship among the three organizational performance measures. These results show that the causal link between service quality and process innovation is the strongest one. 
Table 4. Partial Correlations Among Service Quality, Product Innovation

$\&$ Process Innovation Measures Controlling For The Seven TQM Variables

\begin{tabular}{llll}
\hline & SQ & PRI & PDI \\
\hline SQ & 1.00 & & \\
PRI & $0.261^{* *}$ & 1.00 & 1.00 \\
PDI & $0.210^{* *}$ & $0.229^{* *}$ & \\
\hline
\end{tabular}

** Significant at p<0.01; SQ=Service Quality; PRI=Process Innovation; PDI=product Innovation

\section{DATA ANALYSIS}

\subsection{Test Of Hypothesis H1}

In this hypothesis Service quality represents dependent variable and the seven TQM dimensions Top management support, Customer Focus, Continuous improvement, Quality information system, Service culture, ICT usage and Knowledge sharing act as independent variables. The results in the table $\mathrm{V}$, the value of $\mathrm{R}^{2}=0.731$, which means 73.1 per cent of variance in service quality tend to be described by the seven TQM dimensions. According to the Table 5, Top management support, customer focus, continuous improvement, information system quality, service culture and ICT usage have significant impact on the delivery of service quality. On inspecting the value of Beta, it can be seen that top management support has most significant impact on service quality after that service culture and customer focus. The value of $\mathrm{R}^{2}$ from the table 5 is 0.731 which implies that 73.1 percent of the variation in service quality might be revealed by the TQM dimensions.

Table 5. Regression Results Between TQM Practices And Service Quality

\begin{tabular}{lc}
\hline \multicolumn{1}{c}{ Independent Variables } & Standardized Beta \\
\hline Top Management support & $0.230^{* *}$ \\
Customer Focus & $0.205^{* *}$ \\
Continuous Improvement & $0.157^{* *}$ \\
Information System Quality & $0.110^{*}$ \\
Service Culture & $0.228^{* *}$ \\
ICT usage & $0.189^{* *}$ \\
Knowledge Sharing & 0.045 \\
$\mathrm{R}^{2}$ & 0.731 \\
Adjusted $\mathrm{R}^{2}$ & 0.721 \\
F-value & $70.728^{* *}$ \\
\hline
\end{tabular}

\subsection{Test Of Hypothesis $\mathrm{H} 2$}

In the hypothesis $\mathrm{H} 2$, product innovation is dependent variable and the TQM practices taken as independent variable. The table 6 shows that continuous improvement has most significant influence on the service product innovation followed by ICT usage . The value of $\mathrm{R}^{2}$ indicates that 39.3 percent of the variation in product innovation can be described by TQM dimensions.

Table 6. Regression Results Between TQM Practices And Product Innovation

\begin{tabular}{lc}
\hline \multicolumn{1}{c}{ Independent Variables } & Standardized Beta \\
\hline Top Management support & 0.137 \\
Customer Focus & -0.139 \\
Continuous Improvement & $0.338^{* *}$ \\
Information System Quality & 0.108 \\
Service Culture & 0.028 \\
ICT usage & $0.151^{*}$ \\
Knowledge Sharing & 0.135 \\
$\mathrm{R}^{2}$ & 0.393 \\
Adjusted $\mathrm{R}^{2}$ & 0.370 \\
F-value & $16.845^{* *}$ \\
\hline
\end{tabular}

Note: $* p<0.05 ; * * p<0.01$ 


\subsection{Test Of Hypothesis $\mathrm{H3}$}

In the hypothesis 3, process innovation is a dependent variable and the TQM practices are independent variables. Based on the value of Beta, it is clear from the table 7 that top management support is most influenced variable followed by knowledge sharing and continuous improvement. The value of $\mathrm{R}^{2}$ indicates that 68.3 percent of the variation in process innovation can be described by TQM dimensions.

Table 7. Regression Results Between TQM Practices And Process Innovation

\begin{tabular}{lc}
\hline \multicolumn{1}{c}{ Independent Variables } & Standardized Beta \\
\hline Top Management support & $0.271^{* *}$ \\
Customer Focus & 0.038 \\
Continuous Improvement & $0.220^{* *}$ \\
Information System Quality & $0.150^{*}$ \\
Service Culture & 0.068 \\
ICT usage & $0.127^{*}$ \\
Knowledge Sharing & $0.241^{* *}$ \\
$\mathrm{R}^{2}$ & 0.683 \\
Adjusted $\mathrm{R}^{2}$ & 0.671 \\
F-value & $56.032^{* *}$ \\
\hline
\end{tabular}

Note:*p< $0.05 ; * * \mathrm{p}<0.01$

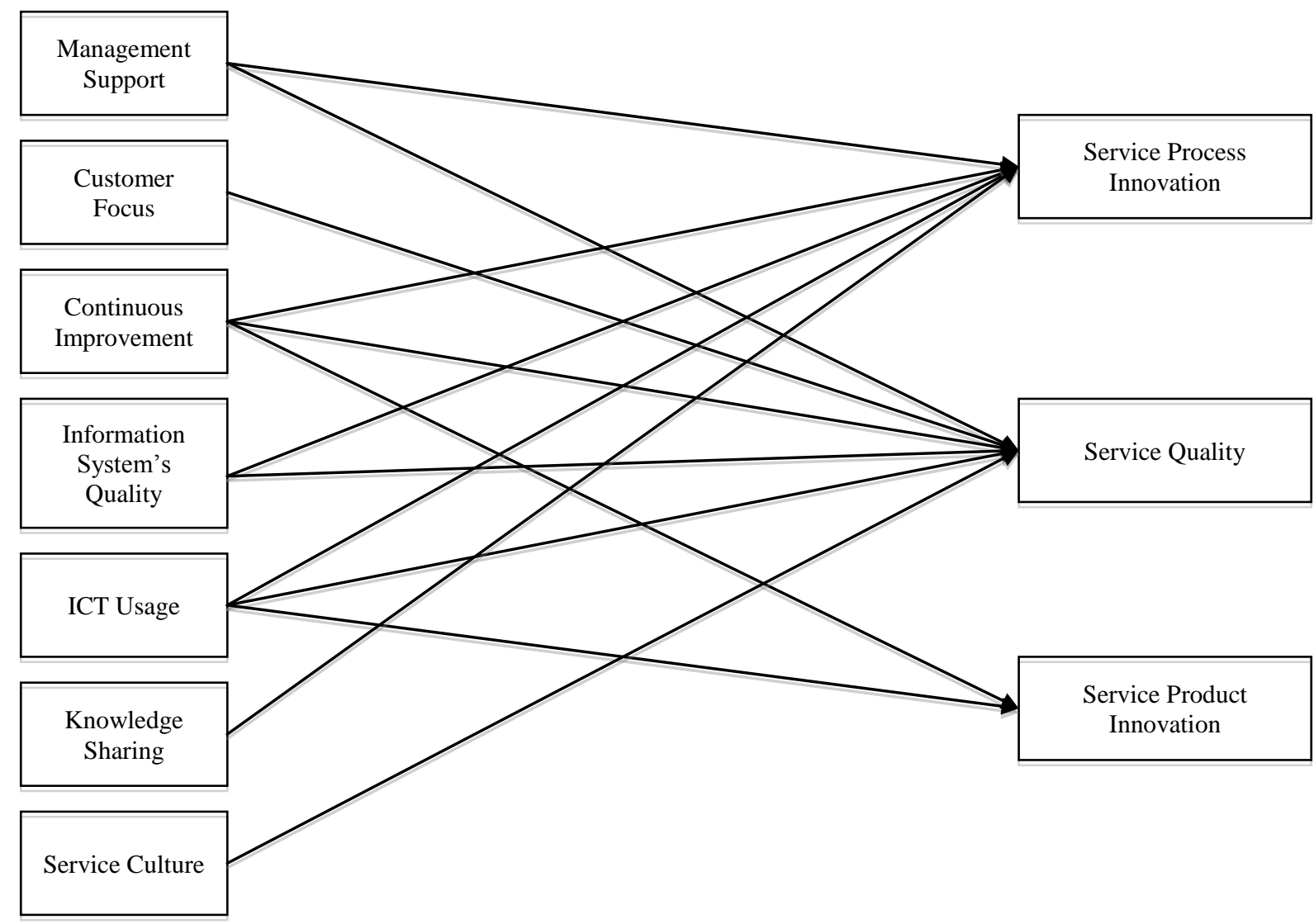

Figure 2. The Revised Model Of The Relationship Between TQM Factors, Service Innovation Practices And Service Quality 


\subsection{Test Of Hypothesis H4}

In the hypothesis 4 , service quality is a dependent variable and the product innovation is an independent variable. The table 8 indicates that product innovation is positively related with service quality .The value of $R^{2}$ indicates that 28.4 percent of the variation in service quality can be described by product innovation.

Table 8. Regression Results Between Service Quality And Product Innovation

\begin{tabular}{lc}
\hline \multicolumn{1}{c}{ Independent Variables } & Standardized Beta \\
\hline Product Innovation & $0.533^{* *}$ \\
$\mathrm{R}^{2}$ & 0.284 \\
Adjusted $\mathrm{R}^{2}$ & 0.280 \\
F-value & $74.675^{* *}$ \\
\hline
\end{tabular}

\subsection{Test Of Hypothesis H5}

In the hypothesis 5, service quality is a dependent variable and the process innovation is an independent variable. The results of the table 9 show that process innovation is positively related with service quality. The value of $\mathrm{R}^{2}$ indicates that 51.5 percent of the variation in service quality can be explained by product innovation. It shows that process innovation plays more significant part in demonstrating the variation in service quality.

Table 9. Regression Results Between Service Quality And Process Innovation

\begin{tabular}{lc}
\hline \multicolumn{1}{c}{ Independent Variables } & Standardized Beta \\
\hline Product Innovation & $0.720^{* *}$ \\
$\mathrm{R}^{2}$ & 0.518 \\
Adjusted $\mathrm{R}^{2}$ & 0.515 \\
F-value & $202.046^{* *}$ \\
\hline
\end{tabular}

\section{DISCUSSIONS}

The implementation of TQM practices has become the important strategy because these practices play significant role in enhancing the business performance in manufacturing and non-manufacturing industries through improving service innovation (Prajogo, 2003) \& (Prajogo, 2008). This study used the seven dimensions of TQM to explain how implementation of TQM practices can improve service innovation practices in financial services firms in Pakistan. The research model of this study and the related hypothesis supports the critical linkage between service innovation practices and service quality. The empirical findings of the study support and validate the hypothesis that TQM implementation improves the Service innovation practices. The TQM practices clearly infer the causal relationship with service quality and service innovation practices. The outcome of this study suggests that service innovation practices acts as vehicle in relation with the implementation of TQM practices in improving the service quality of financial services firms. Our findings supports the arguments of previous studies of (Hoang et al., 2006), (Prajogo, 2003a) and (Prajogo et al., 2003b). The empirical findings of this study reveal that TQM practices have stronger relationship with service process innovation than with service product innovation which supports the results of (Prajogo, 2003b). Also, the relationship of Service process innovation with service quality is stronger than with service product innovation. But, this study like the results of (Singh \& Smith, 2004) (Hoang et al., 2006) could not confirm that all the TQM dimensions play important role in service innovation. Our findings show that five constructs-top management supports, continuous improvement, information system's quality, ICT usage and knowledge sharing to some extent have a positive influence on service process innovation, while continuous improvement and ICT usage is positively related with product innovation

The causal association between service innovation and service quality suggests a positive relationship between them. The overall results inferred that service innovation (product innovation \& process innovation) mediates the relationship between TQM dimensions and service quality in the service company. The strong positive correlation between process innovation and product innovation confirms the findings of (Singh et al., 2004) \& (Kraft, 1990). Besides, the findings of this paper support the positive relationship between TQM and service quality. The recent studies carried out by (Lam, 2012), (Sit et al., 2011) and (Ooi et al, 2011) further confirm the findings of this study. Our analysis confirms that strength of process innovation on service quality is larger than that of product 
innovation. Our findings exhibited that TQM practices affect service quality by using direct along with indirect paths and the effect of direct path is stronger than that of indirect path.

Top management behaviors are important in the service innovation of any service firms. Top management support has positive impact only on service process innovation. Continuous improvement has positive relationship with both product and process innovation. This study suggests that when TQM organic elements as well as TQM technological tools and techniques work together, can enhance the service innovation. Our study confirms that TQM tools and techniques like information system's quality and ICT usage influence service quality and innovation performance. This study contradicts the research works of Powell (1995) and Prajogo and Sohal (2003a) who suggested that only certain tacit resources like employee empowerment and open culture play significant role in innovation performance. The empirical findings of this study reveal that TQM practices have stronger relationship with service process innovation than with service product innovation which supports the results of (Prajogo, 2003b). Also, the relationship of Service process innovation with service quality is stronger than with service product innovation. The financial service companies in Pakistan are using quality information systems that are user-friendly, helpful for effective analysis and are timely accessible. These quality information systems have powerful analytical capabilities like business decision making, querying and reporting, data mining and data visualization. The financial service firms are also using latest technologies for ICT. The quality information systems are supported by ICT technologies. Therefore, these quality information coupled with ICT technologies are supporting financial service firms for innovation performance and service quality.

This research found that the relationship between TQM and service quality was strongest one followed by process innovation and lastly product innovation. The service quality has stronger relationship with process innovation than with product innovation. The weak relationship between TQM and product innovation indicates that TQM has least support in the area of product innovation. The contribution of TQM towards radical product innovation is not so prominent because TQM practices are more market-pull whilst innovations are more productpush (Prajogo and Sohal, 2001). This study suggests that service organizations which focus on improving service quality should look for more innovations in their processes in order to improve their service quality. The service organizations can bring improvements in their service process innovations through the implementation of quality information systems and ICT usage. The service organizations can benefit from the innovations if they are in line with values and objectives of the organization (Klein and Sorra, 1996). Therefore, new technology should be implemented within context of organizational strategic objectives (Prajogo, 2002). The above results are in congruence with propositions suggested by Prajogo(2002) and Gobeli and Brown (1994) that TQM principles are more focused on process innovation than on product innovation because TQM origin is ingrained in the principles of statistical process control(SPC). Our results show that process innovation of service firms is strongly related to both service quality and service product innovation. Thus, overall association between TQM principles, service quality and service innovation is strong one and this reinforces our research framework.

\section{RESEARCH IMPLICATIONS}

The findings of this study throw light on the structural relationship between TQM, service innovation and service quality. This model can be helpful in developing countries in enhancing service innovation and service quality of service organizations. From the managerial point of view this study guides service practitioners that they can bring improvements in their service innovation and service quality by acting on the TQM quality principles. This research guide service providers in an effort to attain superior service innovation and service quality, they should emphasis more on implementing TQM. Also, the research findings of positive effect of service innovation practices on service quality demonstrate the importance of service innovation in improving the service quality of financial service organizations. The service firms should bring service innovation in their services in order to improve service quality. The service firms can achieve competitive strength by presenting better service quality than their competitors. The significant TQM dimensions concerned with service quality are top management support, customer focus, continuous improvement, service culture, information system's quality and ICT usage.

The theoretical framework of this explains the relationship between TQM practices, service innovation practices and service quality. This research also integrates the connection among TQM implementation, Service innovation practices and service quality. Furthermore, service innovation practices play significant role in shaping 
service quality of the service firm. This model throws light on the influence of TQM implementation and service innovation practices are key enablers to the service quality. This empirical research suggests that in order to improve the service quality, service organizations pay attentions to both service process innovation and service product innovation. In addition, researcher should also focus on key TQM dimensions Top management support, continuous improvements, customer focus, information system's quality, ICT usage, service culture and knowledge sharing that will foster service innovation and improve service quality.

The final part of the findings shows that service innovation mediate the relationship between TQM elements and service quality. In particular, the direct effect of TQM on service quality is stronger than that of between service innovation and the service quality. We can say that from this link that implementation of TQM is more directed towards service quality than innovation performance. This shows that TQM is more related with quality performance than innovation performance because the TQM dimensions were developed to pursue high quality performance. The role of TQM dimensions is also critical in service innovations as they offer numerous practical implications for the managers. First, the key role of service innovation practices affecting service quality invites practitioners bring about changes in the design of service products and service delivery process and consequently improve the service quality. The financial firms should continue investing in service innovation to stay competitive, building shareholder value for long term and gain market advantage. Service organizations should look for new innovations that are different from existing one to sustain current customer or attract new customers. The successful service innovations improve service quality because they improve customer satisfaction and customer loyalty which results in positive word of mouth and repeat purchases. It is important for managers to carefully consider the role of TQM practices while taking innovation initiatives. Before considering any new service innovation programs, managers should focus on implementing TQM elements for achieving superior service quality and service innovation.

\section{CONCLUSION}

The intent behind this paper was to explore the connection between TQM practices, service innovation and service quality and develop a conceptual framework. There were few studies who investigated the relationship among TQM elements, service innovation practices and service quality in the service organizations. This study shed light on the usefulness of TQM practices in service industry. Furthermore, it contributes to the existing literature concerning influence of TQM practices on service quality and service innovation. It has numerous benefits for the management of service organizations that are interested in the connection between TQM practices, service innovation and service quality. It is essential for management to know the important TQM practices that results in improving service quality and service innovation in service firms. The management of service firms should further work on enhancing the service quality and service innovation by changing the TQM pratices.

There are few empirical studies which have considered triangulation of TQM practices, service innovation and service quality within the context of financial service firms. In this study, multiple regression analysis was used to generate empirically verified and validated results. The outcomes of this research indicated that TQM implementation has more stronger and positive effect on service quality than on service innovation. Finally, through the mediating role of service innovation practices it was found that TQM elements have a positive and significant impact on service quality. Thus, our findings confirm the triangulations of TQM, service innovation and service quality outperforms the two-way relationship of Service innovation and service quality. The overall implications of the research is that TQM principles provide solid ground for managing service innovation and service quality. The service innovation, particularly process innovation enhances the contribution of TQM towards the attainment of better service quality.

\section{AUTHOR INFORMATION}

Arif Mohammad Arshad is a doctorate student at the Xi'an Jiaotong University in CHINA.

E-mail: marshadarif@yahoo.com

Dr. Qin Su is a professor in the Faculty of Management Sciences at the Xi'an Jiaotong University in CHINA. E-mail: qinsu@mail.xjtu.edu.cn 


\section{REFERENCES}

Ahmadabadi, D. M. N., D. J. Mehrabi, et al. (2012). Modeling the Impact of Total Quality Management (TQM), Practices on Service Quality in Service Organizations (Case Study: Isfahan Refah Kargaran Bank). International Journal of Learning and Development, 2(3).

Al-Hawari, M. and Ward, T. (2006). The effect of automated service quality on Australian banks' financial performance and the mediating role of customer satisfaction. Marketing Intelligence \& Planning, 24(2), 127-47.

American Heritage Dictionary of the English Language (2000). Houghton Mifflin, Boston, MA,available at: www.dictionary.com (accessed 14th June, 2014).

Anton, C., Camarero, C., \& Carrero, M. (2007). The mediating effect of satisfaction on consumers' switching intention. Psychology \& Marketing, 24, 511-538.

Antony, J., Leung, K., Knowles, G. and Gosh, S. (2002). Critical success factors of TQM implementation in Hong Kong industries, International Journal of Quality and Reliability Management, 19(5), 551-66.

Apostolou, D., Mentzas, G., \& Abecker, A. (2008).Managing knowledge at multiple organizational levels using faceted ontologies. Journal of Computer Information Systems, 32-49.

Ar, I. M. and B. Baki (2011). Antecedents and performance impacts of product versus process innovation: Empirical evidence from SMEs located in Turkish science and technology parks. European Journal of Innovation Management, 14(2), 172-206.

Avlonitis, G.J., Papastathopoulou, P. G. \& Gounaris, S.P. (2001). An empirically-based typology of product innovativeness for new financial services: success and failure scenarios. Journal of Product Innovation Management, 18(5), 324-342.

Axtell, C.M., Holman, D.J., Unsworth, K.L., Wall, T.D., Waterson, P.E. and Harrington, E. (2000).Shopfloor innovation: facilitating the suggestion and implementation of ideas. Journal of Occupational and Organizational Psychology, 73, 265-85.

Baldwin, J.R., Johnson, J., (1996). Business strategies in more and less innovative firms in Canada. Research Policy, 25, 785-804.

Berry, L.L., Shankar, V., Parish, J.T., Cadwallader, S. \& Dotzel, T. (2006). Creating new markets through service innovation. Sloan Management Review, 47(2), 56-63.

Bettencourt, L. A., Brown, S. W., \& Sirianni, N. J. (2013).The secret to true service innovation. Business Horizons, 56(1), $13-22$.

Bharati, P. Berg, D. (2003). Managing information systems for service quality: a study from the other side. Information Technology \& People, 16(2), 183-202.

Bon, A. T. and Mustafa, E. M. A. (2013). Impact of Total Quality Management on Innovation in Service Organizations: Literature Review and New Conceptual Framework. Procedia Engineering, 53,516-529.

Bon, A. T., \& Mustafa, E. M. A. (2012).Recent and Influential Studies on TQM-innovation Relationship: A review. International Journal of Management Studies, Statistics and Applied Economics (IJMSAE), 2(2), 147-162.

Brah, S.A., Serene T.S.L. and Rao, B.M. (2002). Relationship between TQM and performance of Singapore companies. International Journal of Quality and Reliability Management, 19(4), 356-79.

Brynjolfsson, E., Hitt, L.M., (2000). Beyond computation, information technology, organizational transformation and business performance. Journal of Economic Perspectives, 14(4), 23-48.

Cainelli, G. Evangelista, R., Savona, M. (2004). The Impact of Innovation on Economic Performance in Services. Service Industries Journal, 24(1), 116-130.

Cainelli, G., Evangelista, R., Savona, M. (2006).Innovation and economic performance in services: a firm-level analysis. Cambridge Journal of Economics. Oxford University Press, 30(3), 435-458.

Chen, J.S. \& Tsou, H.T. (2007). Information technology adoption for service innovation practices and competitive advantage: the case of financial firms. Information Research, 12(3).

Cook, L.S. and Verma, R. (2002). Exploring the Linkages between Quality System, Service Quality, and Performance Excellence: Service Providers' Perspectives. Quality Management Journal, 9(2), 44-56.

Cronin, J. J., Jr., Brady, M. K., \& Hult,G.T. M. (2000). Assessing the effects of quality, value, and customer satisfaction on consumer behavioral intentions in service environments. Journal of Retailing, 76(2), 193-218.

Dale, B.G. (2003). TQM: an overview, in Dale, B.G. (Ed.), Managing Quality (4th ed.). Oxford: Blackwell Publishing.

Damanpour, F., Walker, R. M. and Avellaneda, C. N. (2009). Combinative Effects of Innovation Types and Organizational Performance: A Longitudinal Study of Service Organizations. Journal of Management Studies, 46(4), 650-675.

Davenport, T. H. \& Short, J. E. (1990). The new industrial engineering: information technology and business process redesign. Sloan Management Review, 31(4), 11-27. 
Day, G. S. y Wensley, R. (1988). Assessing Advantage: A Framework for Diagnosing Competitive Superiority. Journal of Marketing, 52, 1-20.

Dean, J.W. Jr and Bowen, D.E. (1994). Management theory and total quality: improving research and practice through theory development. The Academy of Management Review, 19(3), 392-418.

Dedrick, J., Gurbaxani, V., Kraemer, K.L., 2003. Information technology and economic performance: a critical review of the empirical evidence. ACM Computing Surveys, 35(1), 1-28.

Deming, W.E., (1986). Out of the Crisis. Cambridge, MA: MIT Press.

Dewhurst, F.W., Martinez-Lorente, A.R. and Sanchez-Rodriguez, C. (2003). An initial assessment of the influence of IT on TQM: a multiple case study. International Journal of Operations \& Production Management, 23(4), 348-74.

Flynn,B.B.,Schroeder,R.C.and Sakakibara,S.(1994). A framework for quality management research and an associated measurement instrument. Journal of Operations Management, 11,339-66

Garcia, R., and Calantone, R.(2002). A critical look at technological innovation typology and innovativeness terminology: A Literature review. The Journal of Product Innovation Management, 19(2), 110-132.

A service quality model and its marketing implication. European Journal of Marketing, 18(4), 36-44.

Han, B. M., \& Anantatmula, V. S. (2007).Knowledge sharing in large IT organizations: A case study. VINE, 37(4), 421439.

Hoang, D. T., Igel, B., \& Laosirihongthong, T. (2006). The impact of total quality management on innovation: Findings from a developing country. International journal of quality \& reliability management, 23(9), 1092-1117.

Hoffman, R.C. and Hagerty, H. (1994). Top management influence on innovation: effects of executive characteristics and social culture. Journal of Management, 19(3), 549-74.

Iansiti, M. 1995. Shooting the rapids: Managing product development in turbulent environments. California Management Review, 38(1), 37-58.

Jeroen P.J. de Jong, Patrick A.M. Vermeulen, (2003). Organizing successful new service development: a literature review. Management Decision, 41(9),844 - 858.

Johne, A. and Storey, C. (1997).New service development: a review of the literature and annotated bibliography. European Journal of Marketing, 32( 3/4),184 - 251.

Juneja, D., Ahmad, S., \& Kumar, S. (2011). Adaptability of Total Quality Management to Service Sector. International Journal of Computer Science \& Management Studies, 11(2), 93-98.

Juran, J.M., (1988). Juran on Planning for Quality. New York,NY: The Free Press.

Kaplan, S.M., (2000). Innovating Professional Services. Consulting to Management, 11(1), 30-34.

Kersten, W. and Koch, J. (2010). The effect of quality management on the service quality and business success of logistics service providers. International Journal of Quality \& Reliability Management, 27(2), 185-200.

Khazanchi, S., Lewis, M.W. and Boyer, K. (2007). Innovation-supportive culture: the impact of organizational values on process innovation. Journal of Operations Management, 25(4), 871-84.

Kim,J. \& Mueller,C.(1978). Introduction to Factor Analysis. Beverly Hills, CA: Sage Publications.

Klein, K.J. and Sorra, J.S. (1996). The challenge of innovation implementation. Academy of Management Review, 21(4), 1055-80.

Kohli, R., Devaraj, S., (2003). Measuring information technology payoff: a meta-analysis of structural variables in firmlevel empirical research. Information System Research,14(2), 127-145.

Kraft, K. (1990). Are product- and process-innovations independent of each other?. Applied Economics, 22(8), $1029-38$.

Kuczmarski \& Associates, Inc. (1994). Winning New Product and Service Practices for the 1990s. Chicago, IL : Kuczmarski \& Associates, Inc.

Lai, F., Griffin, M., \& Babin, B.J. (2009). How quality, value, image, and satisfaction create loyalty at a Chinese telecom. Journal of Business Research, 62(10), 980-986.

Lam, S.-Y., V.-H. Lee, et al. (2012). A structural equation model of TQM, market orientation and service quality: Evidence from a developing nation. Managing Service Quality, 22(3), 281-309.

Lapierre, J., Denier, A., (2005). ICT adoption and moderating effects of institutional factors on salesperson's communication effectiveness: a contingency study in high-tech industries. Technovation, 25(8), 909-927.

Leavengood, S., \& Anderson, T. R. (2011). Best practices in quality management for innovation performance. Technology Management in the Energy Smart World (PICMET). 2011 Proceedings of PICMET '11, 1-9.

Lee, V.H., Ooi, K.B., Tan, B.I. and Chong, A.Y.L. (2010a). A structural analysis of the relationship between TQM practices and product innovation. Asian Journal of Technology Innovation, 18(1), 73-96.

Lei, L. (2011).The impact of service innovation on business performance: Evidence from firm-level data in Chinese tourism sector. Service Systems and Service Management (ICSSSM), 2011 8th International Conference on.

Lenka, U., Suar, D., \& Mohapatra, P. K. J. (2010). Soft and Hard Aspects of Quality Management Practices Influencing Service Quality and Customer Satisfaction in Manufacturing-oriented Services. Global Business Review, 11(1),79-101. 
Loukis, E., \& Pazalos, K. (2009). An empirical investigation of the moderating effects of BPR and TQM on ICT business value. Journal of Enterprise Information Management, 22(5), 564-586.

Martínez-Costa, M., \& Martínez-Lorente, A. R. (2008). Does quality management foster or hinder innovation. An empirical study of Spanish companies. Total Quality Management \& Business Excellence, 19(3), 209-221.

Martinez-Lorente, A.R., Sanchez-Rodriguez, C. and Dewhurst, F.W. (2004). The effect of information technologies on TQM: an initial analysis. International Journal of Production Economics, 89(1), 77-93.

Matear, S., Grey, B. J. and Garrett, T. (2004). Market orientation, brand investment, new service development, market position and performance for service organizations. International Journal of Service Industry Management, 15(3), 284-301.

Matta, K., Chen, H. G., \& Tama, J. (1998).The Information Requirement of Total Quality Management. Total Quality Management, 9(6), 445-461.

McAdam, R., Armstrong, G. \& Kelly, B. (1998). Investigation of the relationship between total quality and innovation: a research study involving small organizations. European Journal of Innovation Management, 1(3), 139-147.

Melville, N., Kraemer, K.L., Gurbaxani, V. (2004). Information technology and organizational performance: an integrative model of IT business value. MIS Quarterly, 28(22), 283-322.

Menor L, Tatikonda M, Sampson S. (2002). New service development: areas for exploitation and exploration. Journal of Operations Management, 20(2), 135-15.

Mercer Management Consulting, Inc. (1994). High Performance New Product Development: Practices that Set Leaders Apart. Boston, MA: Mercer Management Consulting, Inc.

Mielgo N. P., Poen-Monters J. M, Ordas-Vazquez C. J. (2009). Are quality and innovation management conflicting activities?. Technovation, 29(8), 537-545.

Miles, I. (2005). Innovation in Services, in Fagerberg, J., Mowery, D. and Nelson, R. (eds) Oxford Handbook of Innovation. Oxford.:Oxford University Press.

Mjema, E.A.M, Victor, M.A.M, Mwinuka, M.S.M. (2005). Analysis of roles of IT on quality management. The TQM Magazine, 17(4), 364-374.

Nunnally, J. (1967). Psychometric Theory. New York, NY: McGraw-Hill.

Oke, A. (2007). Innovation types and innovation management practices in service companies. International Journal of Operations \& Production Management, 27(6), 564 - 587.

Ooi, K.B., Cheah, W.C., Lin, B. and Teh, P.L. (2012). TQM Practices and Knowledge Sharing: An Empirical Study of Malaysia's Manufacturing Organizations. Asia Pacific Journal of Management, 29(1), 59-78.

Ooi, K.B., Lin, B., Tan, B.I. and Chong, A.Y.L. (2011). Are TQM practices supporting customer satisfaction and service quality? Journal of Services Marketing, 25(6), 410-9.

Palmer, A. (2001). Principles of Services Marketing (3rd ed.). New York, NY: McGraw-Hill.

Parasuraman, A., Zeithaml, V.A. and Berry, L.L. (1988). SERVQUAL: a multi-tem scale for measuring customer perceptions of service quality. Journal of Retailing, 64(1), 12-40.

Prajogo, D. I. and S. W. Hong (2008). The effect of TQM on performance in R\&D environments: A perspective from South Korean firms. Technovation, 28(12), 855-863.

Prajogo, D. I., \& Sohal, A. S. (2006). The integration of TQM and technology/R\&D management in determining quality and innovation performance. Omega, 34(3), 296-312.

Prajogo, D.I. and Sohal, A.S. (2003a). The multidimensionality of TQM practices in determining quality and innovation performance - an empirical examination. Technovation, 24(6) , 443-453.

Prajogo, D.I. and Sohal, A.S. (2003b). The relationship between TQM practices, quality performance, and innovation performance: an empirical examination. International Journal of Quality \& Reliability Management, $20(8), 901-$ 18.

Prajogo, D.I. and Sohal, A.S. (2006). The relationship between organizational strategy, total quality management (TQM), and organizational performance-the mediating role of TQM. European Journal of Operation Research, 168(1), $35-50$.

Ravichandran,T., Rai, A.(2000). Total quality management in information systems development: key constructs and relationships. Journal of Management Information Systems, 16(3), 119-155.

Reichstein, T. and Salter, A. (2006).Investigating the sources of process innovation among UK manufacturing firms. Industrial and Corporate Change, 15(4), 653-682.

Rönnbäck,A \& Witell, L. (2008). A review of empirical investigations comparing quality initiatives in manufacturing and service organizations, Managing Service Quality, 18(6), 577 - 593.

Ross, J.E. (1999). Total Quality Management, Text, Cases and Readings (3rd ed.). St.Lucie Press.

Samat, N., Ramayah, T., \& Saad, N. M. (2006). TQM practices, service quality, and market orientation: some empirical evidence from a developing country. Management Research News, 29(11), 713-728. 
Sadikoglu, E., \& Zehir, C. (2010). Investigating the effects of innovation and employee performance on the relationship between total quality management practices and firm performance: An empirical study of Turkish firms. International Journal of Production Economics, 127(1), 13-26.

Samat, N., Ramayah, T., \& Saad, N. M. (2006). TQM practices, service quality, and market orientation: some empirical evidence from a developing country. Management Research News, 29(11), 713-728.

Santos, J. (2003). E-Service Quality: A Model of Virtual Service Quality Dimensions. Managing Service Quality, 13(3), 233-46.

Scholtes, P. and Hacquebord, H.(1988). Beginning the Quality Transformation. Quality Progress, 21, 28-33.

Schulteß, P., Wegener, S., Neus, A., \& Satzger, G. (2010). Innovating for and with your service customers: An assessment of the current practice of collaborative service innovation in Germany. Procedia-Social and Behavioral Sciences, 2(4), 6503-6515.

Shams-ur Rahman, (2001). A comparative study of TQM practice and organizational performance of SMEs with and without ISO 9000 certification. International Journal of Quality \& Reliability Management, 18(1), 35 - 49.

Siddiqui, Jamshed and Zillur Rahman (2007). TQM Principles Applications on Information Systems for Empirical Goals: A Study of Indian Organizations. The TQM Magazine, 19(1), 76-87.

Lam, S. Y., Lee, V. H., Ooi, K. B., \& Phusavat, K. (2012). A structural equation model of TQM, market orientation and service quality: evidence from a developing nation. Managing Service Quality, 22(3), 281-309.

Singh, P. J. \& Smith, A. (2004). Relationship between TQM and innovation: an empirical study. Journal of Manufacturing Technology Management, 15(5), 394-01.

Sit, W.Y., Ooi, K.B., Lin, B. and Chong, A.Y.L. (2009). TQM and customer satisfaction in Malaysia's service sector, Industrial Management \& Data Systems, 109(7), 957-75.

Sit, W.Y., Ooi, K.B., Loke, S.P. and Tan, G.W.H. (2011). TQM and service quality: a survey of commercial banking industry in Malaysia. International Journal of Services Economics and Management, 3(1), 78-91.

Sureshchandar, G. S., Rajendran, C., \& Anantharaman, R. N. (2001). A holistic model for total quality service. International Journal of Service Industry Management, 12(4), 378-412.

Sureshchandar, G.S., Rajendran, C. and Anantharaman, R.N. (2002). The relationship between management's perception of total quality service and customer perceptions of service quality.Total Quality Management, 13(1), 69-88.

Takeuchi, H. and Quelch, J.A. (1983). Quality is more than making a good product. Harvard Business Review, 61(4), 13945.

Ueno, A. (2008). Which management practices are contributory to service quality?. International Journal of Quality \& Reliability Management, 25(6), 585-603.

Victorino, L., Verma, R., Plaschka, G., \& Dev, C. (2005). Service innovation and customer choices in the hospitality industry. Managing Service Quality, 15(6), 555-576.

Wang, W. T. (2009). Knowledge management adoption in times of crisis. Industrial Management \& Data Systems, 109(4), 445-462.

Yoo, D.K., Park, J.A. (2007). Perceived service quality - analyzing relationships among employees, customers, and financial performance. International Journal of Quality \& Reliability Management, 24(9), 908-926.

Zahra, S.A. \& Nielsen, A.(2002). Sources of capabilities, integration and technology commercialization. Strategic Management Journal, 23(5), 377-398.

Zairi, M. (2002). Beyond TQM implementation: the new paradigm of TQM sustainability. Total Quality Management, 3(8), 1161-1172.

Zakuan, N.M., Yusof, S.M., Laosirihongthong, T. and Shaharoun, A.M. (2010). Proposed relationship of TQM and organizational performance using structured equation modeling. Total Quality Management, 21(2), 185-203.

Zaltman, G., Duncan, R. \& Holbek, J. (1973). Innovation and organizations. New York, NY: Wiley.

Zehir, C., Ertosun, Ö. G., Zehir, S., \& Müceldilli, B. (2012). Total Quality Management Practices' Effects on Quality Performance and Innovative Performance. Procedia-Social and Behavioral Sciences, 41, 273-280.

Zeithaml, V.A., Parasuraman, A. and Berry, L.L. (1990). Delivering Quality Service. New York, NY: The Free Press.

Zhang, Z., Waszink, A. and Wijngaard, J. (2000). An instrument for measuring TQM implementation for Chinese manufacturing companies. International Journal of Quality \& Reliability Management, 17(7), 730-55.

Zhao, F., \& Bryar, P. (2001). Integrating knowledge management and total quality: a complementary process. In $6 t h$ International Conference on ISO (Vol. 9000). 